\title{
Peculiar Quarantines: The Seamen Acts and Regulatory Authority in the Antebellum South
}

\author{
MICHAEL SCHOEPPNER
}

In 1824, the American schooner Fox sailed into Charleston harbor with seasoned mariner and Rhode Island native Amos Daley on board. When officials boarded the ship, they interrogated the captain and crew before cuffing Daley and hauling him off to the Charleston jail, where he remained until the Fox was set to leave harbor. Daley's detainment occurred because 16 months earlier the South Carolina General Assembly had enacted a statute barring the entrance of all free people of color into the state. Unlike other antebellum state statutes limiting black immigration, this law extended further, stretching to include in its prohibition maritime laborers aboard temporarily docked, commercial vessels. This particular section of the law was passed on the assumption that such sailors inspired slave insurrection and thereby posed a direct threat to the safety and welfare of the citizenry. Over the course of the next four decades, the states of North Carolina, Georgia, Florida, Alabama, Mississippi, Louisiana, and Texas would join South Carolina in passing statutes, commonly referred to as the "Seamen Acts," which limited the

Michael Schoeppner is an American Council of Learned Societies postdoctoral instructor at the California Institute of Technology <mschoepp@caltech.edu>. The author thanks Elizabeth Dale, Jon Sensbach, Sally Hadden, and the anonymous reviewers at Law and History Review, as well as Martha Jones, Edlie Wong, and the other participants of the 2011 "We Must First Take Account" Conference on Race, Law, and History held at the University of Michigan Law School. Financial support was provided by a New Faculty Fellows Award from the American Council of Leamed Societies, funded by the Andrew W. Mellon Foundation. 
ingress of free black mariners. Amos Daley was only one of $\sim 10,000$ sailors directly affected by these particularly Southern regulations. ${ }^{1}$

In court, Daley's attorneys attacked the South Carolina variant on two particular fronts. First, they claimed the recent Supreme Court case of Gibbons v. Ogden invalidated all state regulatory statutes, including the Seamen Act, which interfered with Congress's exclusive authority to regulate interstate and international commerce. Although actually misreading the Great Steamboat Case, Daley's counsel believed that Marshall's strong language in the opinion meant the inevitable demise of seamen restrictions. Second, Daley's attorneys claimed that the law was a blatant violation of the Constitution's Privileges and Immunities Clause. They argued that the clause extended to Daley by virtue of his Rhode Island citizenship, and that South Carolina had no constitutional authority to restrict the sailor's liberty of movement. ${ }^{2}$

The story of Amos Daley is a fitting place to begin this study of the Seamen Acts, because the specific arguments made at his trial serve as a practical shorthand for the ways that legal historians have generally approached this set of laws. They have found them useful when highlighting the meandering Commerce Clause jurisprudence of the antebellum era.

1. State v. Daley reprinted in Charleston Mercury, June 23, 1824. The following list comprises the initial state statutes against black sailors, and when I reference any of the individual Seamen Acts below, I am citing these particular statutes unless otherwise noted. Acts Passed at the Annual Session of the General Assembly of the State of Alabama (Tuscaloosa, 1838), 134-36; Acts of the Legislative Council of the Territory of Florida (1832), 143-45; Laws of the State of Mississippi Passed at a Regular Biennial Session of the Legislature, Held in the City of Jackson in January and February A.D. 1842 (Jackson, 1842), 65-71; Acts Passed at the Second Session of the Fifteenth Legislature of the State of Louisiana: Begun and Held in the City of New-Orleans, December 13, 1841 (New Orleans, 1842), 308-18; General Laws of the Sixth Legislature of the State of Texas, Passed at Its Adjourned Session, Convened July 7, 1856 (Austin, 1857), 48-49; Acts and Resolutions of the General Assembly of the State of South Carolina, Passed in December, 1822 (Columbia, 1823), 11-14; Acts of the General Assembly of the State of Georgia Passed in Nov. and Dec.1829, 168-71; and Acts Passed by the General Assembly of the State of North Carolina at the Session of 1830-1 (Raleigh, 1861), 2931. No reliable statistical evidence exists with which to accurately enumerate the total number of sailors affected by the many Seamen Acts during their enforcement, although W. Jeffrey Bolster puts the number above 10,000. See W. Jeffrey Bolster, Black Jacks: African-American Sailors in the Age of Sail (Cambridge, MA, 1997), 206.

2. Charleston Mercury, June 23, 1824. Daley's attorneys also argued that the Seamen Act should not apply to the sailor because he was not "black," but rather of Native American descent. As the revised 1823 statute targeted sailors specifically "descended from negroes, mulattoes, and mustizos [sic]," Daley ought to have been beyond its reach, despite state witnesses testifying that his "wooly hair" and "dark complexion" disproved his Narragansett heritage. For the amended 1823 South Carolina statute, see David McCord, ed., Statutes at Large of South Carolina, Volume 5, (Columbia, 1839), 220. 
In these accounts, the Seamen Acts both informed and were shaped by an utter lack of consensus regarding the proper interface between state policing authority and federal power over commerce. Other studies have used the Seamen Acts as evidence of the precariousness of African-American citizenship and the failure of interstate comity to guarantee the protection of Northern African-Americans who journeyed South. Often culminating their works with Dred Scott v. Sandford, these histories tend to reduce the Seamen Acts to their influence on judicial doctrine concerning black citizenship in the early republic. In short, the legal historiography of the Seamen Acts has fixated on these two particular constitutional themes. ${ }^{3}$

In this article, I depart from these important studies in two ways. First, the Seamen Acts occupy the center of the story instead of sitting on the

3. For examples of works relating the Seamen Acts to citizenship, see Don Fehrenbacher, The Dred Scott Case: Its Significance in American Law and Politics (New York, 1978) and Austin Allen, Origins of the Dred Scott Case: Jacksonian Jurisprudence and the Supreme Court, 1837-1857 (Athens, GA, 2006). For examples of works linking the Seamen Acts to the Commerce Clause, see Donald Morgan, Justice William Johnson, The First Dissenter: The Career and Constitutional Philosophy of a Jeffersonian Justice (Columbia, SC, 1954); and Norman Williams, "Gibbons," New York University Law Review 79 (2004): 1398-1499. Some scholars have linked citizenship and the Commerce Clause. See, for example, Scott Wallace Stucky, "Elkison v. Deliesseline: Race and the Constitution in South Carolina, 1823," North Carolina Central Law Journal 14 (19831984): 361-405. Also, some other legal scholars have looked to the laws as a way to understand other constitutional issues, such as the treaty-making power and immigration. See David Golove, "Treaty-Making and the Nation: The Historical Foundations of the Nationalist Conception of the Treaty Power," Michigan Law Review 98 (2000): 1075319; and Gerald Neuman, "The Lost Century of American Immigration Law (17761875)," Columbia Law Review 93 (1993): 1833-901. Of course legal historians are not the only scholars to investigate the laws. For decades, the definitive work was a pair of essays in diplomatic history. See Philip Hamer, "Great Britain, the United States, and the Negro Seamen Acts, 1822-1848," Journal of Southern History 1 (1935): 3-28 and Philip Hamer, "British Consuls and the Negro Seamen Acts, 1850-1860," Journal of Southern History 1 (1935): 138-68. For the Seamen Acts place in South Carolina political culture generally, see Alan January, "The First Nullification: The Negro Seamen Acts Controversy in South Carolina, 1822-1860," (PhD diss., University of Iowa, 1976). Literary scholar Edlie Wong has used the Seamen Acts to illustrate broader themes of race and status in nineteenth-century travel literature in Neither Fugitive Nor Free: Atlantic Slavery, Freedom Suits, and the Legal Culture of Travel (New York, 2009). Scholars on free blacks in general and black sailors in particular have talked about the Seamen Acts. For example, Ira Berlin, Slaves without Masters: The Free Negro in the Antebellum South (New York, 1974); John Hope Franklin, The Free Negro In North Carolina, 1790-1860 (Chapel Hill, 1943); H.E. Sterx, The Free Negro in Ante-Bellum Louisiana (Rutherford, NJ, 1972); Peter Linebaugh and Marcus Rediker, The Many-Headed Hydra: Sailors, Slaves, Commoners, and the Hidden History of the Revolutionary Atlantic (Boston, 2000); and W. Jeffrey Bolster, Black Jacks, 198-214. 
periphery. Second, I have chosen a different analytic lens in my examination. Rather than focus on how the Seamen Acts informed specific constitutional developments, such as Commerce Clause or citizenship jurisprudence, I am more concerned with understanding how the laws "happened" in the antebellum South. Taken together, the laws created a specific legal regime of exclusion, a regulatory technology that represented one aspect of what William Novak has described as the "well-regulated society." Although this study largely supports Novak's contention that antebellum Americans acknowledged, even embraced, the necessity of an active and near ubiquitous governmental authority to act for "the people's welfare," it also depicts a very complicated and contested process. Antebellum Southerners may have conceded or even celebrated extensive state regulatory action, but they also disagreed, at times vehemently, about exactly what their regulatory regime ought to look like. They fought over the precise locus and limits of regulatory authority, which threats demanded governmental intervention, and the appropriate means of enforcement. This investigation of the Seamen Acts illustrates some of the ideological, jurisdictional, and institutional friction over regulation that animated the conduct of governance in the antebellum South. The Seamen Acts, like other forms of regulatory law, were constructed and maintained amid a firestorm of competing ideologies, interests, and legal claims. ${ }^{4}$

In the pages that follow, I identify two broad arenas of conflict that arose with the enactment and enforcement of the Seamen Acts. The first arena encompasses debates over the efficacy of regulation. It considers both the contested process by which white Southerners came to identify black sailors as threats to society, and the volatile arguments over the relative merits of regulating them. Were black sailors dangerous, and was it worthwhile for jurisdictions to outlaw their ingress? The answers were never obvious or unanimous. They varied across time and space, and they reveal some of the ideological and economic cleavages within Southern society, as well as shifting international influences. Within the second arena of conflict, the primary question was not if sailors ought to regulated, but how they should or could be regulated. Because of the rather draconian features of many of the laws, protestors offered sharp critiques of enforcement, with some erstwhile critics even employing individual rights or international law as potential limits to regulatory authority. Although I

4. William Novak, The People's Welfare: Law and Regulation in Nineteenth-Century America (Chapel Hill, 1996). Novak sought to prove that a regulatory state actually existed in the nineteenth century United States, a daunting task considering several enduring myths about the American state, or the lack thereof, in the antebellum period. Novak identified several types of regulatory law that permeated the lives of everyday Americans, from statutes securing public safety and security to codes protecting public morals and health. 
separate these two broad arenas in my analysis, I do not mean to suggest that they operated exclusively. Nor do I assert that they exhaust all of the unexplored legal conflicts associated with the Seamen Acts' saga. Rather, they are meant to clarify some of debates over seamen regulations that have escaped legal historians, and to integrate those debates into existing constitutional histories of the laws. ${ }^{5}$

\section{The Policy Debate: Defining the Threat and Assessing the Merits of Regulation}

In this section, I describe the contested process by which free black sailors became identified as dangerous outsiders, and subsequently targeted for specific forms of regulation. Even before Nathaniel Turner's revolt canonized the term "outside agitation" and infused it with robust explanatory power regarding the incidence of slave revolt, some white Southerners were deploying the related idea of "moral contagion" to describe catalysts for racial unrest. Beginning in South Carolina in 1822 and radiating outward, many white Southerners considered foreign (i.e., from beyond their respective states) free blacks to be inherently corrupted-or infected-and intent on undermining the Southern slave system. Free black sailors emerged as a particular cause of concern. Both state and local authorities enacted specific regulations geared toward thwarting the ingress of these dangerous sailors and thereby prevent poisonous ideas from creating an epidemic among local slaves. From the very outset, however, white Southerners fought over the presence of "moral contagion" and the relative merits of seamen regulation. By barring the entrance black sailors, these laws also interrupted commercial networks and threatened immediate and long-lasting economic problems for the merchants and traders in Southern port cities.

\section{Discovering a Moral Contagion}

The origins of the first Seamen Act are quite easy to discern. The law came into effect in South Carolina in 1822 immediately following the infamous

5. Space constraints prevent the inclusion of a third arena of conflict that addresses the jurisdiction of regulation. This sphere concerns not if or how the sailors should be regulated, but what authority was competent to make such determinations. Questions regarding extraterritorial jurisdiction, federal relations, and local-state relations animated this particular arena. For a similar approach to local-state debates, see Laura Edwards, The People and Their Peace: Legal Culture and the Transformation of Inequality in the PostRevolutionary South (Chapel Hill, 2009). 
Denmark Vesey Conspiracy. During that summer, more than 100 slaves and free blacks allegedly coordinated the largest slave rebellion in United States history. Although no overt acts of insurrection actually occurred, investigators and trial courts meted out swift and severe punishment, often with scant evidence. With people's taste for sensationalism piqued, and with the city in a state of collective shock, dozens of convicted conspirators were hanged from the gallows, and many more were exiled from the state. ${ }^{6}$

The city's white population constructed a narrative of causation for the botched revolt, and within it Denmark Vesey assumed Herculean characteristics. He was the mastermind, and because of his central role, white Charlestonians sought to explain the impetus behind his murderous designs. Mayor James Hamilton wrote that Vesey was once an Atlantic-savvy sailor who had traveled for years around the revolutionary Atlantic and even resided in St. Domingue immediately before the Haitian Revolution. The official trial "transcripts," which were actually authored after the executions by two of the sitting magistrates, confidently proclaimed that Vesey kept close contact with transnational black sailors. These men apparently linked Charleston to Haiti and West Africa. The "transcripts" also revealed to eager readers Vesey's recruitment strategies. Anonymous witnesses supposedly testified that Vesey often recounted stories of Haiti's glory to win converts and inspire his legions. In this way, city officials portrayed Vesey as the propeller of insurrection, the contaminating influence on otherwise passive local slaves. ${ }^{7}$

This concept of contamination as a prime catalyst for the rebellion suggested to some people that governmental officials ought to be much more diligent in sifting through the messages being introduced from abroad. Because the dangerous Atlantic helped inspire the Vesey conspiracy, (or at least this is what people used as a rationale) only a new program of Atlantic exchange, one anchored by a systematic rejection of dangerous people and ideologies, could prevent another such insurrection in the

6. Robert Tinkler, James Hamilton of South Carolina (Baton Rouge, 1994); and Edward Pearson, Designs against Charleston, The Trial Record of the Denmark Vesey Slave Conspiracy of 1822 (Chapel Hill, 1999), Appendix 2.

7. James Hamilton, An Account of the Late Intended Insurrection among a Portion of the Blacks of the City of Charleston, South Carolina (Charleston, 1822); and Lionel H. Kennedy and Thomas Parker, An Official Report of the Trial of Sundry Negroes Charged with an Attempt to Raise an Insurrection in the State of South Carolina (Charleston, 1822). See also Wong, Neither Fugitive Nor Free, 184-96. This reading of the Vesey affair does not preclude the simultaneous apprehension that white Charlestonians maintained over local free people of color. Many of the authors cited above also harbored deep suspicions about the city's freemen. My point is to highlight the changing attitudes toward outsiders. 
future. Newspaper editors, attorneys, city officials, and others sought to couple local adjustments to port regulation with statewide statutory reforms regarding free people of color, in the hope of containing these dangerous forces. Both municipal authorities and the South Carolina legislature took these suggestions to heart. In addition to outlawing the permanent immigration of free people of color, the state General Assembly also barred the temporary ingress of all free people of color from outside the state, including workers aboard commercial vessels. According to the new law, if any such maritime laborer arrived in port, local sheriffs were to escort him to jail until his vessel was set to leave the harbor. ${ }^{8}$

The exploding narrative of contamination found its first champion in Charleston attorney Benjamin Hunt. It was Hunt who first made an explicit and emphatic link between biological contagion and the dangers posed by Atlantic-savvy black sailors. In defending the law against black sailors in federal court in 1823, Hunt proclaimed, "We have much more reason to believe in the moral contagion they introduce, than in the importation of yellow-fever... In South Carolina, we think the presence of a free negro, fresh from the lectures of an Abolition Society equally dangerous." Although Hunt may have been first, he was not alone, and others expanded on the contagion theme. One editorialist quipped, "To permit such persons... [as the] colored population into this state from the North and elsewhere, with their known habits, feelings, and principles, animated and emboldened as they are by the philanthropy of the day... is to introduce a moral pestilence which is to destroy subordination in the slave, and with it the state itself... It is a moral contagion. It is the Upas Tree, whose touch is death." Another article pinpointed the origins of the contagion in the French and Haitian Revolutions, "from which came licentiousness... irreligion, atheism, and every species of madness and every wrong principle of enthusiasm."

8. For some examples of the calls for legislative changes in the aftermath of Vesey, see Achates [Thomas Pinckney], Reflections, Occasioned by the late Disturbances in Charleston (Charleston, 1822); "Memorial of the Citizens of Charleston to the Senate and House of Representatives of the State of South Carolina" (Charleston, 1822), in $A$ Documentary History of American Industrial Society, ed. John R. Commons et al. (Cleveland, 1910), 2:104-13; and Edwin Holland, "A Refutation of Calumnies Circulated Against the Southern and Western States..." (Charleston, 1822). in Denmark Vesey: The Slave Conspiracy of 1822, ed. Robert Starobin (Upper Saddle River, NJ, 1970). On the increased dangers of Atlantic abolitionism, see, for example, [Robert Turnbull and Isaac Holmes], "Caroliniensis No. 5," Charleston Mercury, August 22, 1823.

9. Benjamin F. Hunt, "The Argument of Benj. Faneuil Hunt in the case of the arrest of the Person claiming to be a British Seaman, under the 3d section of the State Act of Dec. 1822, in relation to Negroes, \&c before the Hon. Judge Johnson, Circuit Judge of the United States, for the 6th Circuit" (Charleston, 1823), in Slavery, Race, and the American Legal System, 
The rhetorical power of "contagion" was immense, and Hunt and his compatriots were clever to deploy it. The early republic was a very sickly place, and the only thing that could spread with greater speed and malignancy than contagious disease was the fear of an imminent pandemic. Although scientists and medical men disagreed about "contagionism"the belief that epidemic diseases traveled from an infected person to a healthy person-most laypeople were sound adherents of the philosophy. News of contagion and epidemic shook cities and towns during the period, invoking the specter of mass death, the collapse of government, and the breakdown of society. When Benjamin Hunt compared black sailors to people infected with yellow fever, he was speaking a language Americans understood all too well. ${ }^{10}$

The application of the rhetoric of contagion to black Atlantic mariners expanded far beyond the city of Charleston. In 1829, Boston clothier David Walker published An Appeal to the Coloured Persons of the World, a manifesto that called for slaves and free blacks across the Atlantic to demand their liberty, and if denied, to resort to bloody insurrection. When port officials in New Bern and Wilmington, North Carolina and Savannah, Georgia uncovered clandestine shipments of the "dangerous pamphlet," lawmakers in both states sprang into action. In addition to criminalizing slave literacy and the introduction of "incendiary" materials, the legislatures in both states also enacted laws against black sailors on the assumption that they would be the likely distributors of Walker's Appeal. Quite revealingly, both legislatures codified their regulations of black sailors under the banner "Quarantine," suggesting the deep inroads the contagion narrative had made from its Charleston birthplace. ${ }^{11}$

By labeling the laws explicitly as "quarantines," lawmakers in North Carolina and Georgia perpetuated the discourse as well. In 1831, North

1700-1872, ed. Paul Finkelman (New York, 1988), 2:2-3; and Charleston Mercury, September 6 and 13, 1823.

10. On contagionism and epidemic disease in the early republic, see Alan Kraut, Silent Travelers: Germs, Genes, and the "Immigrant Menace" (Baltimore, 1995), 11-49; John H. Howell, Bring Out Your Dead: The Great Plague of Yellow Fever in Philadelphia in 1793 (Philadelphia, 1949); Charles Rosenberg, The Cholera Years: The United States in 1832, 1849, and 1866 (Chicago, 1962, 1987); and several of the essays in Charles Rosenberg and Janet Golden, eds., Framing Disease: Studies in Cultural History (New Brunswick, 1997). Also helpful is Martin Pernick, "Contagion and Culture," American Literary History 14 (2002): 858-65.

11. Hasan Crocket, "The Incendiary Pamphlet: David Walker's Appeal in Georgia," Journal of Negro History 86 (2001): 305-18; Clement Eaton, "A Dangerous Pamphlet in the Old South," Journal of Southern History 3 (1936), 325-32; and Cary Howard, "The Georgia Reaction to David Walker's Appeal," (Master's Thesis, University of Georgia, 1967). 
Carolina Superior Court Judge Robert Strange instructed the jury in a case against "quarantined" British mariners, "As a state, in her own sovereign capacity, has a right. . to prevent the introduction within her limits of febrile or pestiferous contagion, so has a state an equal right to legislate to prevent the influence of moral contagion." In Georgia, state officials were so persuasive in their deployment of the contagion-quarantine language they convinced British officials in London to acquiesce to the regulation. According to one member of the Board of Trade, the quarantine might be "absurd," but because the Georgia government supposed itself in "extreme jeopardy," it could pass whatever measures it wanted to, to "avert a supposed danger" without compromising any bilateral agreement or "the law of Nations." 12

Expositors of the contagion narrative accumulated a host of new adherents during the early 1830s. In 1831, Nathaniel Turner rampaged through Southampton, Virginia, leaving dozens dead and thousands more terrified of an imminent race war. Following Turner's arrest and confession, Virginia officials attributed his motivations to the "outside agitation" of - Baptist ministers and radical abolitionist writers, who supposedly infected the precocious slave. Later the same year, Jamaican authorities blamed subversive Baptist missionaries for instigating the massive Christmas Rebellion that left dozens of plantations in flames and Jamaican authorities fearful of a Haitian-style revolution. Convinced that insurrection was being introduced from without, Jamaican officials demanded an immediate end to Baptist missionary activity on the island. Well aware of both rebellions and the "outside agitation" that supposedly inspired them, the territorial legislature in Florida enacted its own Seamen Act in 1832. The "contagion of liberty" would not infect Florida slaves without a fight from legislators. ${ }^{13}$

12. Robert Strange graduated from Washington College in Lexington, Virginia before his family moved to Fayetteville, North Carolina. Strange studied law there, was admitted to the state bar, and was elected to the State General Assembly in 1821. During the mid-1820s, Strange became a dedicated Jacksonian. From 1826 until 1836, he served as a superior court judge before being appointed to the United States Senate to complete the vacated term of Willie Mangum. Strange was elected to his own term in the United States Senate the next year. In 1840 , he resigned rather than succumb to the dictates of the newly ascendant Whig state legislature. See William S. Powell, ed., Dictionary of North Carolina Biography (Chapel Hill, 1994), 5:489; and "Hon. Robert Strange," United States Monthly Law Magazine 5 (1852): 321-22. On British acquiescence to the Georgia Seamen Act, see James Stephen to [Thomas] Lack, March 16, 1830 in Correspondence relative to the Prohibition against the Admission of Free Persons of Colour into certain Ports of the United States, 1823-1851, Series 5, Volume 579, Foreign Office Papers, UK National Archives, Kew, England (hereafter Correspondence), 20-22.

13. Edward Rugemer has charted the "outside agitation" trope in certain spheres of United States public discourse. See Rugemer, The Problem of Emancipation: The Caribbean Roots 
In 1835, the complementary concepts of "outside agitation" and "moral contagion" revealed their currency in the thunderous response to Lewis Tappan's polarizing abolitionist mail campaign. When Southern areas were inundated with hundreds of thousands of antislavery pamphlets, assemblies in nearly every Southern state responded in unison. They forcefully endorsed their own unilateral authority to police their borders against dangerous outsiders and infectious ideas as a means to prevent slave insurrection. According to Bertram Wyatt-Brown, "torchlight parades, raucous oratory and protest meetings greeted the antislavery pamphlets" and "almost every major city and town in the region held anti-abolitionist rallies." When four free black sailors entered Mobile, Alabama from the steamship Warsaw, and were discovered to have a package of "incendiary newspapers," they were immediately taken into custody. Within months, the state legislature decried "the malignant designs of the Abolitionists," who were "sending to our country their agents" and "lighting up fires of discord in the bosoms of our slave population." At the next state legislative session, the Alabama Seamen Act was codified. ${ }^{14}$

By the time the Alabama Seamen Act went into effect, even the United States Supreme Court affirmed the rhetorical and legal power of the contagion narrative. In the 1837 case New York v. Miln, the Court reinforced the power of the states to enact "precautionary measures" aimed at curtailing the introduction of "moral pestilence." In other words, local and state laws that served as border regulations were a central component of the police power and beyond federal and perhaps even judicial intervention. Subsequently, when the Gulf states of Mississippi (1842), Louisiana (1842), and Texas (1856) enacted their own restrictions against black sailors, they could rely on the powerful, well-worn, and even Supreme Court-sanctioned concept of "moral contagion." 15

of the American Civil War (Baton Rouge, 2007). See Tallahassee Floridian, February 21, 1832. The Florida Seamen Act was also passed in February. The term "contagion of liberty" comes from the final chapter of Bernard Bailyn, The Ideological Origins of the American Revolution (Cambridge, MA, 1967).

14. For Southem reactions to the Mail Campaign, see Michael Kent Curtis, "Curious History of Attempts to Suppress Antislavery Speech, Press, and Petition in 1835-1837," Northwestern University Law Review 89 (1995), 785-870; and Bertram Wyatt-Brown, "The Abolitionists' Postal Campaign of 1835," Journal of Negro History 50 (1965), 227-38. On Alabama's reaction, see Mike Mansfield, "An Onerous and Unnecessary Burden': Mobile and the Negro Seamen Acts," Gulf South Historical Review 21 (2005): 14-15; Resolution passed January 9, 1836 in Acts of Alabama (1835-1836), 174-75. Other states passed similar sorts of resolutions. For example, Acts of Virginia (1835), 44-45; and Acts and Resolutions of North Carolina (1835-1836), 119-21.

15. New York v. Miln, 36 U.S. 102 (1837), 191. 
As powerful as the discourse of "moral contagion" became, some commentators denied outright this logic undergirding the Seamen Acts. Some of these writers questioned the power and desire of free black sailors to accomplish the dreaded designs assigned them by anxious lawmakers. For them, no contagion existed. In South Carolina, even in the midst of the Vesey affair, then Governor Thomas Bennett excoriated local officials in Charleston who created public anxiety by conducting the trials in "secrecy and seclusion." Bennett's brother-in-law, Supreme Court Justice William Johnson, lamented the hysteria that gripped the city and its legal system during the trials of the conspirators. City officials were to blame, in Johnson's esteem, as they had grossly overreacted to "a few ignorant penniless unarmed uncombined fanatics." The new law was politically motivated, a way for public officers to justify their apparent lack of discretion. "To magnify danger," Johnson explained with extraordinary pithiness, "is to magnify the claims of those who arrest it." If Johnson had borrowed the language of his opponents, he might have said that the doctors had created a panic of contagion to enhance their own social importance. Thirty years later, some Charlestonians still denied the possibility of moral contagion. In 1855, the Charleston Mercury pressed for liberalization of the Seamen Act and proclaimed, "there is no danger, and in fact those who oppose the change know well enough that there is no danger." 16

Other Southerners shared this sentiment. In 1850s Mobile, Democratic Party operatives denied the proposition that black sailors posed an existential threat to Alabama society. According to one editorial, "the provisions [of the Seamen Act] are no longer necessary" because "the poor trembling free blacks who come here [are] far more frightened at us terrible slaveholders, and more in offending, than intent on doing mischief." Some North Carolinians, too, denied the presence of moral contagion. In Wilmington, British Consul Charles Peshall informed his superiors that most of the city's "inhabitants were averse to the law." He may have been correct, as North Carolina lawmakers rescinded the "quarantine" after only a year on the books. For historian Ira Berlin, this was proof positive that white North Carolinians "viewed black sailors as no more dangerous than their own free Negro populations." In many Southern port cities, then, critics directly questioned the veracity of the contagion narrative and

16. Printed circular of Governor Thomas Bennett, August 10, 1822 in Denmark Vesey: The Slave Conspiracy of 1822, 92. William Johnson to Thomas Jefferson, December 10, 1822, from Donald Morgan, Justice William Johnson, The First Dissenter, 138. The Charleston Mercury article was reprinted in other cities. See, for example, Washington, DC's The National Era, December 20, 1855, 203. 
doubted that the presence of foreign free black sailors substantially elevated the likelihood of slave insurrection. ${ }^{17}$

\section{The Potency of Infection}

The Southerners who denied outright the presence of "moral contagion" among free black sailors were certainly in the minority, especially in the aftermath of Nathaniel Turner's Revolt, the Christmas Rebellion and the abolitionist mail campaign. However, they were often joined in their derision of the laws by other, more careful commentators who questioned not the presence of contagion, but rather its potency. For them, free black sailors did pose a threat, but that threat was relatively small. Any systematic attempt to exclude them would only produce results far worse than if the men were allowed to move about unchecked. For these critics, the threat of contagion paled in comparison to the economic catastrophe attending to the diminution of commerce. In these instances, we see what Brian Schoen highlighted in The Fragile Fabric of Union, a seeming paradox within the Cotton South between free trade purists obsessed with accelerating market activity and their more socially conservative counterparts preoccupied with the security of the plantation. ${ }^{18}$

Evidence of this friction can be found across the geography and duration of the Seamen Acts' existence. In the late 1820s, Charleston merchants and their representatives in the General Assembly attempted time and again to have the law jettisoned from the statute book. In 1826, the Charleston Chamber of Commerce sent a lengthy memorial to the General Assembly requesting an amendment to the law, as its current form had brought "an end to our trade with British ports." The lower house agreed, but the state Senate failed to act, earning even the scorn of the Charleston Mercury. In 1843, the South Carolina House once again contemplated liberalization to appease "those who trade with us." No one less than Benjamin Hunt-the attorney who had defended the Seamen Act 20

17. Mansfield, "'An Onerous and Unnecessary Burden," 21; Mobile Daily Register, December 19, 1856. For Peshall's remarks, see C[harles] J. Peshall to [Anthony] St. John Baker, December 24, 1831, in Correspondence, 37-38. Ira Berlin, Slaves without Masters, 215-16. Berlin's conclusion regarding the Upper South is likely correct. Virginia, Delaware, and Maryland never passed Seamen Acts. However, his evidence for North Carolina is faulty. Although the North Carolina Assembly rescinded the Seamen Act in 1831, Wilmington city officials enacted municipal port regulations with a mandatory imprisonment feature a decade later. A copy of the regulation can be found in Correspondence, 96-98.

18. Brian Schoen, The Fragile Fabric of Union: Cotton, Federal Politics, and the Global Origins of the Civil War (Baltimore, 2009), 116-18. 
years earlier-voted in favor of amendment because of the law's effect on "the business of the metropolis [Charleston]."19

In 1842, when the Alabama Seamen Act was only 3 years old, members of the Mobile upper crust debated the efficacy of maintaining regulations against free black sailors. More commercially minded commentators feared that the continuance of the law would decimate the profitable Caribbean trade, while advocates of law-and-order lambasted city officials who did not thoroughly enforce the law against all incoming mariners. The law was left intact, although municipal authorities were reluctant to enforce it. For them, it was better to risk the contempt of state lawmakers than alienate the city's small but powerful mercantile elite. A decade later, Mobile Democrats led a charge to have the Seamen Act expunged from the books because it operated "prejudicially to the commerce of Mobile...without the corresponding benefit as a measure of police protection." The law was simply an "onerous and unnecessary burden." At one point, local shipmasters even organized a public protest and parade in which they burned an effigy of an "informer" who reported to the sheriff infractions against the Seamen Act. ${ }^{20}$

In New Orleans, the economic problems with the Seamen Act proceeded along similar lines but without the pageantry. Before 1852, the city's three municipalities operated independently, and, according to historian Richard Tansey, the "merchants in each district sought to increase their share of the city's trade by persuading the police not to seize out-of-state free blacks" as dictated by Louisiana law. According to one justice of the peace, "If they [the sailors] were to be arrested according to our ordinances, the proprietors would take their steamers to Lafayette where their colored employees would be undisturbed." The fluctuating labor market and ability of free blacks to drive down labor costs put law enforcement officials in an untenable situation. State statutes and white laborers demanded immediate incarceration (at least until 1852, when the law was amended), whereas merchants, ship captains, and the sizable local free black population pressed to have the law ignored. Over the two-decade lifespan of the Louisiana Seamen Act, enforcement was intermittent, and incoming sailors were never quite sure of their fate when entering the Crescent City. By 1852, the state legislature conceded to the economic arguments of New Orleans' merchants and the haphazard enforcement of local officials. That year, the Louisiana Seamen Act was amended to allow maritime

19. Charleston Courier, April 11, 1826; Charleston Mercury, December 25, 1826; Alan January, "The First Nullification," 229-32. The debate over the House bill to amend the Seamen Act occurred on December 15, 1843, and is reprinted in Correspondence, 71-74. 20. Mansfield, "'An Onerous and Unnecessary Burden,"' 18-23. 
workers to secure a municipal passport to allow them to come ashore. The fear of economic decline could prove to be as frightening as the moral contagion of liberty, at least until 1859 , when the mandatory imprisonment feature was reinstated in direct response to John Brown's raid. ${ }^{21}$

In 1854, the Georgia state legislature mimicked Louisiana and liberalized its Seamen Act. When it did, it conveyed its rationale in the very language of the statute. "Whereas the interests of commerce require an alteration of the laws now of force relating to the arrival of colored seamen," black sailors could remain aboard their vessels and even come ashore once they had received explicit permission from local authorities. One of the key orchestrators of the Georgia amendment was the Senate president, whose sister was married to the British consul in Savannah. The consul met informally with state lawmakers and convinced them of the monetary benefits of adjustment. A case of champagne sealed the deal. Likewise, in North Carolina, both British and American merchants in Wilmington disparaged the 1830 Seamen Act, "which shackles commerce much" and "will effectually destroy the British West Indian trade throughout the state." After "five vessels from St. Vincent and Barbadoes [sic]... proceeded to New York" rather than suffer the effects of the law, the North Carolina Assembly rescinded the statute outright. ${ }^{22}$

The mid-1850s was the period in which economic arguments seemed to make the most headway. This time period also coincided with a concerted effort on the part of the British Foreign Office to refrain from protesting against the laws to federal officials in Washington. In Georgia, Alabama, South Carolina, and Louisiana, the mandatory imprisonment feature was abandoned. In each case, British consular agents were intimately involved in the liberalization. Informal efforts, geared at motivating free-trade merchants in state assemblies, succeeded where formal diplomatic efforts had failed previously. However, we must not overstate the Seamen Acts' demise. Texas enacted its restrictions in 1856 and Louisiana strengthened its own in 1859.23

21. Richard Tansey, "Out-of-State Free Blacks in Late Antebellum New Orleans," Louisiana History 22 (1981), 370-75. Magistrate quote taken from New Orleans Daily Delta, March 27, 1851.

22. Acts of Georgia, 1853-1854, 106-7; and Philip Hamer, "British Consuls," 143. C [harles] J. Peshall to [Charles] Bankhead, October 31, 1831 and C[harles] J. Peshall to [Anthony] St. John Baker, December 24, 1831, in Correspondence, 31 and 37-38.

23. The most-cited scholar of the Seamen Acts, Philip Hamer concluded that British Consuls were successful in their diplomatic assault on the Seamen Acts, even though he acknowledges the statutory changes in Texas and Louisiana. See Hamer, "British Consuls," 167. On the complex and often contradictory representations of slaves generally, see Ariela Gross, Double Character: Slavery and Mastery in the Antebellum Courtroom 


\section{The Administration Debate: Critiques of Enforcement and Methods of Resistance}

Up to this point, I have emphasized the contagion narrative as a key variable in the policy debates over the perceived threats of black sailors and the relative importance of regulating their movement in Southern port cities. However, the contagion narrative had direct legal consequences beyond its ability to sway policy makers and legislators. Considering the prevalence if not the unanimity of the contagion narrative, it might not be surprising to find that many of the early proponents of the Seamen Acts described the laws as akin to quarantine measures. And as long as the debates over the Seamen Acts remained ensconced within the contagionquarantine narrative, the matter of regulation was simply an issue of policing policy. Beyond convincing lawmakers to rescind the law (or pleading with law enforcement to turn a blind eye), few remedies were available to aggrieved parties unhappy with a particular quarantine measure. ${ }^{24}$

However, as rhetorically and constitutionally effective as the quarantine analogy was for the laws' defenders, it also suggested that the laws had potential limits in their means of enforcement. For anyone who cared to look, the Seamen Acts rarely operated like standard quarantine measures. Both the statutory language of the laws and the harsh methods of enforcement undermined the laws' analogy to quarantine, and opened up the law to protests based on its failure to resemble laws that curbed biological contaminants. Thus, the very rationale of "contagion" and "quarantine" that motivated and sanctioned the laws, also served to identify potential limits to the ways in which the laws might have been enforced. Because the laws did not resemble quarantines, some protestors argued, the laws ought to be changed to make the quarantine analogy applicable. To this end, they chided Southern lawmakers to make good faith efforts to conform the Seamen Acts to quarantine measures and allow sailors to remain aboard their vessels. Other protestors went much further, denying that the power of a particular jurisdiction to restrict sailors innocent of all crime was a form of policing. Instead, they offered distinct legal challenges predicated on individual rights and international law, and implied that the regulatory

(Princeton, 2000); and Sarah Roth, "Rebels and Martyrs: The Debate Over Slavery in American Popular Culture. 1822 1865," (PhD diss., University of Virginia, 2002).

24. On the limited legal remedies, see Roger B. Taney to Edwar'd Livingston, June 9 , 1832, Roll 73, Miscellaneous Letters, Records of the Department of State, RG 59, (National Archives, College Park, MD). Recently, a draft of the opinion was published by H. Jefferson Powell in "Attorney General Taney and the South Carolina Police Bill," Green Bag 5 (2001): 75-102. 
power of government was not limitless. Unfortunately for the sailors, these legal challenges only reinforced the fears of outside agitation that initially led to the regulation of black sailors. Consequently, no jurisdiction conceded the power of individual rights to limit state power to regulate dangerous outsiders, whether they be morally or biologically contagious. In the end, nonlegal forms of resistance proved to be the most successful means of countering the regulations.

\section{The Quarantine Analogy}

Early proponents of the Seamen Acts summoned the rhetoric of quarantine in the same breath in which they proclaimed the threat of "moral contagion." Again, Charleston attorney Benjamin Hunt was prescient, framing the Seamen Acts as legally analogous to quarantine. In federal court in 1823, Hunt proclaimed, "New-York subjects our vessels to quarantine, and confines our citizens to hospitals...Yet if we confine her negro cooks... we are told it is a violation of the Constitution!... However, as New-York judges for herself upon one point, South Carolina has the same right to decide on the other." Some lawmakers even made the quarantine connection explicit within the actual statute. As mentioned, in North Carolina and Georgia, the laws were purposefully engrossed as "quarantines." United States Attorney General and Georgia native John Berrien agreed. In 1831, he wrote in defense of the Seamen Acts by declaring them identical to quarantine and beyond the reach of the federal government. The states could adopt whatever measures they wished to protect the safety of their citizenry from whatever menace they identified, and these measures would be protected under the Tenth Amendment. Over time, the Taney Court would uphold state police laws such as quarantine aimed at stopping the introduction of dangerous people or things. ${ }^{25}$

The terms "contagion" and "quarantine" proved to be quite valuable in defending the states' ability to restrict their shores against perceived threats and from federal intervention. However, the quarantine analogy belied the actual forms of regulation that Seamen Acts assumed. In three distinct ways, the Seamen Acts departed from other quarantine measures. Mandatory incarceration, slave exemptions, and the brutal treatment of

25. See James Stephen to [Thomas] Lack, March 16, 1830, in Correspondence, 20-22. Berrien's opinion can be found in United States Congress, House of Representatives, Commerce Committee, Free Colored Seamen-Majority and Minority Reports, 27 Cong., 3 sess., Jan. 20, 1843, 49-58. See also Michael Schoeppner, "Legitimating Quarantine: Moral Contagions, the Commerce Clause, and the Limits of Gibbons v. Ogden," Journal of Southern Legal History 17 (2009): 81-120; New York v. Miln, 36 U.S. 102 (1837); The License Cases, 46 U.S. 504 (1847). 
the sailors undermined the analogy and provoked questions about the functional limits of regulatory authority.

Nearly every Seamen Act contained an immediate incarceration feature. Although some states allowed intermittently for black mariners to remain on board their ships, imprisonment was the standard mode of enforcement, at least until the early-to-mid-1850s. North Carolina was the exception that proved the rule. Its initial statute in 1830 did not include a mandatory incarceration feature, only requiring vessels with free black sailors to ride quarantine for 30 days. However, the law did not survive its first judicial test. In superior court, Judge Robert Strange instructed the jury to consider the quarantine unconstitutional because of its ineffectiveness. For Strange, a 30 day quarantine, after which the sailors would have free rein, did not remedy the infection. "How then," one report paraphrased Strange's charge, "is the nuisance removed or the danger lessened by this law?" Although Strange did not proclaim that imprisonment was necessary, the only realistic way for the state to keep its Seamen Act and still allow many foreign ships to dock was to confine the sailors. At the next session of the North Carolina General Assembly, state lawmakers repealed the law, and a few years later, the Wilmington municipal authorities reinstated a similar code with an imprisonment mandate. ${ }^{26}$

In Charleston, New Orleans, Mobile, and other Southern port cities, jails were segregated by race. The detainment facilities that held black Atlantic sailors also housed delinquent local slaves and free people of color. In other words, most Seamen Acts required that "morally contagious" sailors be held in close proximity to the most "susceptible" population in the city. Some contemporaries noted the obvious problems associated with the forced detainment of sailors in jail, especially considering how naturally the discussions of the Seamen Acts became part of a larger question of quarantine. Supreme Court Justice William Johnson retorted, "If there are evil persons abroad who would steal to this place [Charleston] and do us mischief... then this method of disposing of offenders by detaining them here [in jail] presents the finest facilities in the world for... pursuing their designs." In a similar vein, an attorney for the King of England informed the Foreign Office in 1832 that the incarceration mandate was certainly "a misapplication of quarantine" and unconnected with "the preservation of health." The president of the British Board of Trade in 1824 went even further, "These Yankees may kidnap one another, but they must not kidnap British subjects." With less vitriol, the British consul in

26. For a copy of Judge Strange's charge to the jury, in which he articulated this interpretation of the law, see Correspondence, 36. For a reprint of the Wilmington code, see Correspondence, 98. 
Charleston sent a letter to the state governor in 1853 . The law was obnoxious not because it singled out free blacks, but because it "conveyed [British Seamen] as felons through the public streets." In 1844, a joint committee in the Massachusetts General Court used similar language when it lambasted South Carolina for "casting [crewmen] into prison... without the necessity of alleging against them the commission of any crime."27

Beyond mandatory imprisonment, the statutory language of the Seamen Acts also contained another problematic feature that undermined their correlation to quarantines. Every single Seamen Act in the United States, without exception, specifically barred "free people of color," "free blacks," or "free negroes." In no jurisdiction did the law against maritime workers extend to slaves. As a class, they were entirely exempt. The pervasiveness of slave exemptions within the language of the statues suggests this was no simple oversight. In fact, as the Georgia legislature contemplated enacting its first "quarantine" in 1829, Governor George Gilmer sought to have the restriction apply not only to free blacks, but to slaves from Maryland and Virginia as well. The Georgia Assembly chose to ignore Gilmer's suggestion, leaving slaves out of the new regulation. ${ }^{28}$

One early case from South Carolina is also illustrative. James Calder was a British merchant who lived in Charleston and invested in a British sloop that made regular runs out of the city. When his vessel arrived in January 1823, a deputy sheriff boarded it and interrogated the crew. Hoping to avoid the potentially harsh slave codes, the deckhands all claimed to be free men of color, obviously ignorant of the new law against free black sailors. Their declarations caused their immediate arrests. In court, Calder explained that his men were not actually free, as they claimed during the interrogation, but his slaves. As the statute did not explicitly include slaves, Calder argued, their arrests were in error. Therefore, the state should release his men and refund his jail fees. The state constitutional court found Calder's argument persuasive. They read the statute narrowly and agreed that slaves ought to be exempt from the law. If the legislature had wished to include slaves in the quarantine, it would have specified so in the statute itself. Because of this finding and the legal assumption of slave status for all people of color in South Carolina, the burden of proving the men's free status fell back on the state. When the prosecution could not offer any

27. Johnson quote found in Elkison v. Deliesseline, 8 F. Cas. 493 (1823), 496. W[illiam] Huskisson to [Joseph] Planta, February 4, 1824 and Herbert Jenner to Viscount Palmerston, March 23, 1832, both in Correspondence, 6 and 39-40. For the confidential letter to the South Carolina Govemor, see Hamer, "British Consuls," 164. A copy of the declaration issued by the joint commission in the Massachusetts General Court is reprinted in Niles' National Register, February 22, 1845, 394-399.

28. Hasan Crocket, "The Incendiary Pamphlet," 310. 
further evidence to prove that the sailors were free, judgment was filed for Calder, and he received his refund. ${ }^{29}$

But why should slaves be exempt if the goal of the Seamen Act was to prevent the introduction of "morally contagious" abolitionist ideas? Certainly slaves were as susceptible to such "ailments" of liberty as free people of color. They could just as easily transmit dangerous ideas to local slaves. After all, was not Denmark Vesey himself a slave when he became infected by his Atlantic travels? And was not the overarching fear that free black sailors would "infect" slaves if they were allowed free access to the wharves in Southern port cities? So why would slaves be exempt in every single statute unless the actual goal had little to do with abolitionist speech or writing? Curiously, however, commentators at the time rarely pointed to this obvious paradox in the so-called racial quarantines. ${ }^{30}$

Third, the forms of enforcement further undermined the quarantine analogy and blazed a path for specific legal and constitutional attacks against the Seamen Acts. I opened this article with a brief description of Amos Daley. In 1824, he entered the Charleston port aboard the schooner Fox, where he was arrested and hauled to the local jail. After his arguments concerning the Commerce Clause and the Privileges and Immunities Clause failed, Daley was taken to the local whipping post outside the slave workhouse and given thirteen lashes. ${ }^{31}$ Nearly 20 years later, a British sailor named John Jones was imprisoned in Charleston, and during his confinement, the city jailor told Jones to sweep the jailhouse. Initially, the mariner obliged. Later, some slaves who were incarcerated with Jones told him that his chore was usually reserved for slaves. A few days later, when the jailor again told Jones to sweep the facility, he refused. The jailor proceeded to beat Jones with a stick for his recalcitrance. The beating was so severe that Jones's captain complained to the British Consul, who then forwarded news of the incident to the Foreign Office. The severity of Jones's injuries even flabbergasted South Carolina Governor and rabid firebrand James Henry Hammond. ${ }^{32}$

29. Calder v. Deliesseline, Harper 186 (South Carolina Constitutional Court, 1824); and James Calder to Consul Moodie, January 15, 1823 in Correspondence, 2-3.

30. See, for example, Michael Kent Curtis, Free Speech, "The People's Darling Privilege": Struggles for Freedom of Expression in American History (Durham, 2000).

31. State v. Daley was reprinted in Charleston Mercury, June 23, 1824.

32. For Fraser, see William Ogilby to C[harles] R. Vaughn, November 29, 1830, in Correspondence, 23-24. Diplomatic reverberations are found through the next five pages. For Jones, see William Ogilby to Sheriff of Charleston, November 3, 1843 and William Ogilby to Earl of Aberdeen, November 4, 1843, both in Correspondence, 62-63. For Hammond's response, see Message of the Governor of South Carolina, November 30, 1843, reprinted in Correspondence, 69. See also Carol Bleser, ed., Secret and Sacred: The Diaries of James Henry Hammond, a Southern Slaveholder (New York, 1988), 117. 
The poor treatment of sailors in jail was not confined to Charleston. In Mobile, a stewardess named Mary Frances Roberts was removed from her vessel and placed in jail according to the 1837 Alabama Seamen Act. The toothless white jailor must have fancied Roberts, the world traveler. $\mathrm{He}$ attempted to woo Mary by complimenting her on her extensive travels and her beaming set of pearly whites. When his seduction failed, he turned to force. According to her affidavit, Mary barely escaped him, thanks largely to a random passer-by who distracted her assailant. When she talked about the episode to a fellow prisoner, she discovered that most of the female inmates, all slaves, faced similar advances-turned-assaults. The next day, Mary informed her captain, who then sought legal counsel in hopes of drawing up charges against the jailor. ${ }^{33}$

New Orleans was nearly as nefarious, at least when the law was actually being enforced. Law enforcement officials seemingly used unsuspecting sailors as a reserve workforce. One justice of the peace routinely sent sailors to the slave workhouse rather than the parish prison, as state law required. From the workhouse, the sailors were doled out to municipal authorities and private contractors. At one point, if we believe reports in the National Anti-Slavery Standard, the city's detainment facilities maintained a multitude of sailors who had been in custody from 6 months to 3 years. Abolitionists claimed to have letters written by such sailors, who begged for family and friends to send money lest they remain permanent fixtures in the city jails. Especially after 1850 , abolitionist periodicals routinely harped on morally derelict captains and the conniving jailors of New Orleans. Even the governor of the Bahamas warned sailors and the Colonial Office about this prototype of convict leasing. ${ }^{34}$

In 1835, a local justice of the peace in Key West, Florida, sentenced a free black Bahamian sailor named William Forster to 5 years' enslavement according to the territory's Seamen Act. Later that week, Forster was sold to the highest bidder. The winner of the auction, the man who would literally own Forster for the next half decade, happened to be the very magistrate who sentenced him. When news of Forster's enslavement, not to mention the obvious conflict of interest surrounding his eventual purchase, hit the British Foreign Office, its diplomats demanded the immediate intervention of the United States Department of State. Citing international law and bilateral treaty agreements, Foreign Secretary Palmerston pressed for Forster's

33. The deposition of Mary Frances Roberts was enclosed in Consul Grigg to Viscount Palmerston, January 25, 1848, in Correspondence, 113-14.

34. National Anti-Slavery Standard, October 8 and October 15, 1846; George B. Shattock, The Bahamian Islands (New York, 1905), 563-65; and Wong, Neither Fugitive Nor Free, 184-239. 
immediate release. In apologetic terms but sarcastic tones, the Jackson administration refused to intercede, and the British were not prepared to reinforce diplomatic pressure with economic or military threats. ${ }^{35}$

For these commentators, the Seamen Acts had nothing to do with the quarantine of moral contagion. But such a conclusion only holds if we assume that the moral contagion was confined to abolitionist speech or antislavery literature. If that was the extent of the contagion, then these objectors to the laws-as-quarantines had legitimate qualms. However, the statutes and their enforcement suggest an alternative understanding of contagion. Apparently, the sailors were not just perceived simply as distributors of dangerous words; they were seen as living examples of legal alternatives to race-based, chattel slavery as the foundation for the social order. White Southerners routinely used law and custom to marginalize local free blacks and attempt to prove the totality of white hegemony. Sojourning free black sailors, on the other hand, lived outside this power structure, and their mobility and autonomy served as obvious examples of the geographic limits of that hegemony. In this view the contagion was autonomy, the presence of people of color existing beyond the legal scope of local and state lawmakers. The message, then, was actually inscribed on the very bodies of the free sailors and transmitted by the work they commenced on the docks and wharves. If the mariners were simply left aboard their vessels, they could still be a shining example of the spatial limits of legal authority. But by bringing the black workers ashore in chains, by whipping them at slave whipping posts, by attempting to rape them, by forcing them to work on plantations, or by literally enslaving them, enforcers of the Seamen Acts could powerfully and visibly extend their own authority. They could use the relative autonomy of the sailors to their own ends by stripping the sailors of that autonomy. ${ }^{36}$

35. Viscount Palmerston to Charles Vaughn, September 23, 1835; Charles Bankhead to Viscount Palmerston, December 5, 1835; Charles Bankhead to United States Secretary of State [John] Forsyth, November 14, 1835; John Forsyth to [Charles] Bankhead, November 20, 1835; and Charles Bankhead to Viscount Palmerston, December 21, 1835, all found in Correspondence, 47-50. In South Carolina (for a time), Florida, Texas, and Mississippi, the law permitted the courts to sentence repeat violators to enslavement. This facet of the law earned the ire of Atlantic abolitionist groups, who often proclaimed that Southern courts enslaved hundreds of sailors each year. Although court records cannot sustain them, these stories of punitive enslavement gained increasing currency in the late $1840 \mathrm{~s}$ and into the 1850s, and swayed public opinion in parts of the North and Great Britain. See Wong, Neither Fugitive Nor Free, 183-239.

36. This analysis of the enforcement mechanisms echoes the work of Orlando Patterson. In his groundbreaking book, Slavery and Social Death, Patterson describes a process by which slaveowners took "control of symbolic instruments" that isolated the slave "from all 'rights' or claims of birth" or "any legitimate social order." The state either abetted 
As a result, the more the sailors and their agents resisted the Seamen Acts, the more the sailors exercised autonomy, the greater the perceived necessity of quarantine and the greater the symbolic value of degradation. A brief example will suffice. When John Jones refused to sweep the Charleston jail in 1843, his act of defiance only reinforced the representation of Jones-the-autonomous-sailor as existing beyond the usual power of local law. By defying the jailor, Jones was exhibiting the sort of political activity that was supposed to be quarantined aboard his ship. When the jailor used direct, physical violence and maimed Jones, he enhanced the symbolism of the degradation and once again removed the "contagion" of autonomy. Even the testimony of the jailor confirmed that his use of force was the best way to stem Jones's public insubordination and to prevent slaves from imitating Jones's defiance. ${ }^{37}$

\section{Forms of Resistance}

The imperfect relationship between standard quarantines and most of the Seamen Acts motivated some sailors and their agents to formally contest the laws as inappropriate exercises of regulatory authority. Some couched their arguments within the discourse of individual rights, seeing liberty of movement as a barrier to the police power. In 1823, a Jamaican mulatto named Henry Elkison sued in federal court, claiming that existing Anglo-American treaties protected him while working in Charleston. The 1815 Commercial Convention between the United States and Great Britain specifically prevented the passage of laws "abridging their [British subjects] rights to free ingress and egress, and occupying houses and warehouses for the purposes of commerce." Elkison stoutly declared his status as a bona fide British subject and the inclusion of black sailors under the broad protections of the 1815 treaty. According to Elkison, his subjecthood rested on his birth. He was born free in Jamaica, a British dominion; therefore, he was a subject of the British king. Elkison ended up

actively in this process, or removed itself from the master-slave relationship so as to render the master's control over his slave's social life complete. Symbolic actions were crucial in constructing the legal parameters of slavery and enforcing control of servile populations. The legal edifice on which slavery was sustained relied on performative practices that underscored the slave's alienation from the formal social and legal order. The stories of these sailors complicate Patterson's notion of natal alienation precisely because they were not slaves. The treatment they received was a direct function of their non-slave status. Orlando Patterson, Slavery and Social Death (Cambridge, MA, 1982).

37. The jailor's version of the events, which largely reinforce this contempt for autonomy, can be found in Message of the Governor of South Carolina, November 30, 1843, reprinted in Correspondence, 69-70. 
losing his case because of a jurisdictional problem with his habeas corpus petition, but Justice William Johnson denied the quarantine analogy, accepted the sailor's claim as a British subject, and declared him eligible to work without molestation in the United States. In the aftermath of the case, several prominent South Carolinians debated whether or not Jamaican mulattoes were really rights-bearing subjects of the British Crown. ${ }^{38}$

Similarly, in 1852, a British sailor named Reuben Roberts sued Charleston Sheriff Jeremiah Yates for damages, claiming his arrest under the Seamen Act violated his rights as a British subject as outlined in trade agreements made between the United States and Britain. Roberts lost his case in federal court, and the British Foreign Office forced the sailor to drop his suit just before it emerged on the United States Supreme Court docket. Apparently, the new Tory ministry hoped to leverage the threat of an adverse Supreme Court decision to persuade South Carolina officials to rescind the statute voluntarily. That same year, a Portuguese cook named Manual Pereira sought a writ of habeas corpus in state court in South Carolina. The mariner cited treaties the United States had signed with Britain (he was aboard a British vessel) and with Portugal, the latter of which specifically protected "reciprocal liberty of commerce and navigation" to "the citizens and subjects of their respective states." Like Roberts and Elkison, Pereira claimed that his freeborn birth on Portuguese soil entitled him to protections as outlined in the treaty. An appellate court in South Carolina threw out the case after Pereira was released from custody and escorted out of the state. In no case in the antebellum era did claims of individual rights, predicated on existing treaty law, succeed in either state or federal court. ${ }^{39}$

Claims of individual rights were not limited to international seamen. As mentioned previously, Amos Daley contested his imprisonment in 1824, claiming (among other things) that the Privileges and Immunities Clause in the Constitution guaranteed him, a citizen of Rhode Island, open access to the ports of Charleston. He carried with him freedom papers, and his captain and first mate swore under oath that Daley was a state citizen of

38. Elkison v. Deliesseline, 8 F. Cas. 493 (1823). Michael Schoeppner, "Status across Borders in the Age of Emancipation: Roger Taney, Black British Subjects, and a Diplomatic Antecedent to Dred Scott," Journal of American History (forthcoming).

39. Mathew to Malmesbury, April 24, 1852, in Correspondence, 242-44. A reprint of Pereira's petition is enclosed with Mathew to Malmesbury, May 1, 1852, in Correspondence, 255-58. Ex-Parte Pereira, 6 Rich. 149 (1853), also reprinted in Correspondence, 266; Francis C. Adams, Manuel Pereira: or, The Sovereign Rule of South Carolina with views of Southern Laws, Life, and Hospitality (Washington, DC, 1853); Roberts v. Yates, 20 F. Cas. 937 (1853). 
Rhode Island. Their personal knowledge of Daley and his parents served to reinforce his political legitimacy. In their eyes as in Daley's, his free birth, personal relationships, and legal documents were enough to establish his citizenship credentials. And attached to those credentials was a constitutional right to move freely about the country. ${ }^{40}$

Similar sorts of rights claims were brought before legislatures as well. In 1823, a collection of "Northern Masters" petitioned the federal House of Representatives to intercede and preempt the South Carolina Seamen Act. For the petitioners, in addition to its unconstitutional interruption of interstate commerce, the law also "infringed on the rights of freemen" as laid out in the Privileges and Immunities Clause. Similarly, in 1842, a group of African-Americans in Boston resolved to petition Congress for intercession in the Seamen Acts. Their argument must have been somewhat persuasive, as a group of prominent white Bostonians seconded their position and also memorialized Congress. Among the names on the petition of protest was that of future Supreme Court justice and dissenter in Dred Scott, Benjamin R. Curtis. They hoped Congress would "grant them [the sailors] relief, and render effectual in their behalf the privileges of citizenship secured by the Constitution." 41

A community of Afro-Britons in the Bahamas shared a similar conception of rights when they came together to protest the atrocious treatment of their countrymen in the maritime industry. They petitioned Colonial Governor John Gregory and implicitly Queen Victoria in their $1850 \mathrm{mem}-$ orial against the Seamen Acts in force in the United States. They praised British emancipation, by which the Crown "was pleased to extend the blessings of freedom" to "coloured subjects. . . with a view of raising them in the scale of society" and "by which they became entitled to exercise all the rights and privileges of British subjects." But the Seamen Acts betrayed the promise of emancipation because "Her Majesty's coloured subjects do not enjoy the same privileges as the whites are allowed on their arrival as British subjects at any of the Southern ports of the United States of

40. This was certainly the case in Wilmington, North Carolina, where British consul Charles Peshall forced two sailors to break quarantine, and then underwrote from personal funds the suit bringing the state Seamen Act before the North Carolina Superior Court. See letters between Peshall and the British Consulate General in Correspondence, 31-36. For the story of Daley, see Charleston Mercury, June 23, 1824.

41. "Memorial of sundry masters of American vessels lying in the port of Charleston, S.C.," Niles' Weekly Register, March 15, 1823, 31-32. "Resolutions Adopted at a Meeting of Boston Negroes, October 27, 1842" reprinted in Liberator, November 4, $1842,174-75$. The memorial to Congress is reprinted in United States Congress, House of Representatives, Commerce Committee, Free Colored Seamen-Majority and Minority Reports, 27 Cong., 3 sess., Jan. 20, 1843, 7-9. See also, Wong, Neither Fugitive Nor Free, 187-88. 
America." In their esteem, the Crown was obligated to demand from the United States the equal protection of treaty law by preventing Southern officials from perpetrating "indignity[ies] unbecoming the subject[s] of Her Majesty." 42

Nearly identical language flowed from the pens of state officials in Massachusetts. In the early 1840 s, the state sent noted Concord attorney Samuel Hoar to Charleston to initiate a suit in federal court on behalf of any incarcerated sailors from Massachusetts. After Hoar was escorted (or evicted, as accounts vary) out of South Carolina, a joint committee in the Massachusetts legislature wrote an elaborate rebuke regarding the fiasco. In it, the committee denied that South Carolina "has a right to inflict corporal punishment, by the application of the lash... upon the persons or citizens of Massachusetts." It also questioned the right of any state "to punish by fine and imprisonment, any citizen coming from another state." Along these lines, the police powers of the states had stark and finite limits, some of which were defined by the rights of individual persons and citizens moving across the nation. ${ }^{43}$

These rights claims lodged to or by executive and legislative authorities failed as miserably as those made in federal and state courts. In 1823, 1843, 1850 , and 1860 , Congress flatly refused to intercede either in its capacity to regulate interstate commerce or in recognition of black citizenship rights, assuming any action would initiate disunion. The British Foreign Office, too, never supplemented diplomatic pressure with economic sanctions or military threats. Even at the height of Whig progressivism in the 1830 s, it never moved beyond supplication, and none of the antebellum Anglo-American treaties ever mentioned Afro-British sailors. On the one recorded occasion when a British captain threatened to mount his canons if Wilmington officials tried to remove his black sailors, the Foreign Office refused to endorse his actions. Even the rhapsody of scorn flowing from the state of Massachusetts lacked "manly bearing," to borrow the words of abolitionist editor David Child. Even though Bay State lawmakers proclaimed that a "resort to arms" would be justified to defend their black citizens, they nonetheless refused "to give loose to a spirit of retaliation" and, instead, offered only an "earnest appeal." 44

42. "Memorial to his Excellency John Gregory...," in Correspondence, 132-33.

43. "Massachusetts \& South Carolina", Niles National Register, February 22, 1845, 394-99.

44. The one instance of armed resistance by a captain was the Susan King fiasco in Wilmington in 1846, and the British Foreign Office did not condone the action. See Correspondence, 90-99. David Child quote from "Mr. Child's Speech", Liberator, July 27, 1833, 105. "Massachusetts \& South Carolina", Niles National Register, February 22, $1845,394-99$. 
In both the United States and Great Britain, some jurists denied outright the power of individual rights or international law to impair the Seamen Acts in particular or regulatory authority generally, regardless of the color of the individual. But even for those who might have been flirting with the idea of rights as a shield against government, the protection of black rights was easily bartered for other political or economic concerns. ${ }^{45}$ Formal assaults on the Seamen Acts faltered with these failures of rights claims in Congress, in court, and in Anglo-American diplomacy. Unsurprisingly, informal and extralegal resistance proved far more effective in combating the laws and securing liberalization. In fact, when objectors couched their protests in terms of noblesse oblige, economic calculus, or even Victorian sexual norms, they were much more successful in securing liberalization of the laws or a relaxation in enforcement. In other words, when the laws' detractors approached the Seamen Acts as a matter of policy to be corrected by Southern authorities-as opposed to a matter of international or constitutional law to be determined by others - they were much more successful.

In February, 1846, a British missionary to Jamaica named Hope Waddell entered a port in Mississippi as a result of shipwreck. He arrived with his wife, four young children, and "a maid-servant of the coloured class named Frances Moulton, aged between eleven and twelve years." When the young girl was taken off the vessel under the state's Seamen Act, Waddell hailed the local British consul, begging him to interfere to protect the rights of the "young... British subject." The consul doubted anything could be done, but he nonetheless provided a letter to the mayor begging that the child be released from custody and placed back in Waddell's care. Interestingly, the letter did not harp on international relations or the sanctity of the Union Jack. Rather, the letter sought an exemption for the young Moulton "in consideration not only for the unfortunate circumstance which forced us... into that port, but also for her tender years and her being engaged in waiting on [Waddell's] children, who might suffer from the loss of her services." The mayor instructed the district attorney to refrain from issuing an order of arrest, and after taking careful measurement of Moulton's adolescent body, the court allowed her to stay in Waddell's care, so long as they made quick exit from the state. ${ }^{46}$

We have already heard part of the story of Mary Roberts, the British stewardess who narrowly escaped the sexual advances of the Mobile jailor.

45. See, for example, Michael Kent Curtis, Free Speech, "The People's Darling Privilege": Struggles for Freedom of Expression in American History (Durham, 2000). and Clement Eaton, Freedom of Thought in the Old South (New York, 1951).

46. John Scoble to Viscount Palmerston, September 25, 1846, in Correspondence, 91-94. 
After hearing Roberts's story, her captain hired an attorney and filed a complaint against the jailor. Although no formal charges ever materialized, the episode provided significant leverage for the British Consul in Mobile and the Foreign Office. Rather than confront Alabama officials with legalistic language harping on the individual rights of the stewardess, they instead tapped into prevailing gender and racial norms to amplify the jailor's transgression and illustrate the potential danger of mandatory incarceration. In other words, the jailor's behavior was reprehensible not because he violated the legal rights of a British subject, but because he abused his power and authority over a defenseless and/or racially inferior woman. $\mathrm{He}$ was contemptible more for his violation of well-established, Victorian sexual norms than for his degradation of the Union Jack. British negotiators capitalized on Roberts's unfortunate experience by emphasizing the possibility of similar transgressions in the future. At their next session, Alabama lawmakers removed the immediate incarceration feature from the statute book. ${ }^{47}$

The most amazing example is the story of William Forster, the Bahamian sailor sentenced to 5 years' enslavement in Key West. As Crown officials disputed among themselves and as the Foreign Office revealed the limits of its displeasure, Forster's former captain came to the mariner's rescue. For reasons unrecorded, he returned to Key West, sought out Forster's owner, and bought back his former employee. Although the Florida court had demanded Fraser serve for 5 years, his captain's purse was enough to countermand the dictates of the court's ruling. In all, Forster lived as an American slave for less than 6 months. ${ }^{48}$

As historian Philip Hamer has shown, the British Foreign Office eventually realized the benefits of informal and nonlegal "negotiations." By 1853, the British Foreign Office decided to make informal manipulation the modus operandi for dealing with the Seamen Acts. Consequently, it forced Reuben Roberts to drop his suit against Charleston Sheriff Jeremiah Yates just as the case was about to come before the United States Supreme Court. South Carolina lawmakers eventually responded to Britain's "attitude of friendly remonstrance" by amending its law to allow British sailors to remain aboard their vessels and even to come ashore if they secured a passport from municipal officials. As mentioned earlier, the British consul in Savannah helped procure a similar sort of relaxation when he convinced the president of the state senate, a relative of the consul's wife, to author an amendment. There was not talk of rights,

47. W. Giffard Nicolas to Viscount Palmerston, May 25, 1848, in Correspondence, 122-23; and Acts of Alabama (1848), 130-31.

48. Documents regarding the Forster affair can be found in Correspondence, 47-50. 
of treaty violations, of a degraded Union Jack; there were only informal talks among very prominent and wealthy members of the Savannah elite. And when the Louisiana legislature reinstated the immediate incarceration feature in 1859, the British Consul in New Orleans was able to exploit the economic needs of New Orleans' merchants to convince the municipal police chief to ignore Afro-British sailors, although Northern African-Americans were still targeted. In short, when British merchants, consuls, and diplomats emphasized policy instead of law, Southern policy makers often honored the efforts. Interestingly, this shift away from black rights by British officials mirrored a larger cultural shift away from the racial progressivism of the $1830 \mathrm{~s}$. It is little wonder that informal, nonlegal British efforts in this context of the 1850 s were more successful than counterparts from the Northern United States, where abolitionists and antislavery constitutionalists were gaining public support. ${ }^{49}$

\section{Conclusion}

Although overtly constitutional issues such as the Commerce Clause and citizenship are vital elements of the legal history of the Seamen Acts, the laws also offer an excellent vantage point from which to explore regulatory authority in the Old South. They provide detailed examples of how a particular form of regulation was envisioned, enacted, and enforced. They also highlight some of the political and legal dynamics at work when various groups confronted, defended, and protested this species of regulatory law. Because the Seamen Acts so blatantly deviated from regular sorts of border enforcement measures such as quarantine, critics crafted complex arguments based on individual rights to refute the unilateral power of state governments to police their shores. Although these legal challenges were largely unsuccessful, their very mention made informal suggestions for moderate amendments all the more palatable. When lawmakers responded to these less confrontational overtures and removed the harshest features of enforcement, they dulled the sting of rights-based protests and appeased British consular agents and local merchants at the same time.

49. Philip Hamer, "British Consuls and the Negro Seamen Acts, 1850-1860." On British views toward emancipation and colonial racial policy, see Catherine Hall, Civilising Subjects: Metropole and Colony in the English Imagination, 1830-1867 (Chicago, 2002). On public perceptions of slave character, see Roth, "Rebels and Martyrs." On antislavery constitutionalism, see William Wiecek, The Sources of Antislavery Constitutionalism in America, 1760-1848 (Ithaca, NY, 1977). 